\title{
TRANSITION FROM ECONOMIC GROWTH TO GREEN GROWTH: GREEN BUDGETING*
}

\author{
Fatma YAPICI ${ }^{1}$
}

\begin{abstract}
The 20th century has been a period in which the nations have made remarkable progress in terms of economic, social and technological aspects, and the national incomes rose rapidly especially for the nations that completed the industrialization process in the early period. While all these advances have taken place rapidly, the capacity of the environment, which is the area where the natural resources and the constant interaction with the nations and constitute the direct source of all the lives and activities of the nations, have been ignored. Within the framework of this view, all living and non-living beings in the world have been used for the welfare and happiness of communities. Today, the effects and possible consequences of the natural resources put forward by the scientific circles, the reduction of biodiversity, acid rains, deforestation, depletion of the ozone layer, environmental pollution, and finally global climate changes, also called global warming, began to change the view of the environment from the utilitarian to the ecological-centered view. This study aims to signify "green budgeting" as a tool to states in accordance with the ecological perspective against environmental problems and to demonstrate the tool components of green budgets. In the study, firstly the rationale of green budgeting will be mentioned and the components and necessities of green budgeting will be indicated. As a result, our evaluations and suggestions on green budgeting will be given.
\end{abstract}

Keywords: Environmental problems, sustainable development, green budgeting, environmental taxes.

JEL Code: Q56, Q01, H61, H23.

\section{Introduction}

Since 1970s, human activities, especially economic ones, caused by environmental destruction and extinction scientists are brought to the agenda. Our current period was called as Millennium Age, and it was met with great expectations in technology and science. While the advances in technology and science do not make the expectation unfair, increasing global warming and the threat of global climate change have brought a period in which societies such as melting of glaciers, rising temperatures and tsunami disasters are deeply affected and thus the debates on this issue are spreading from the scientific circles to political circles. The fulfillment of the requirements for the prevention of possible environmental disasters has come to the fore. On the other hand, it is considered that actions should be taken to reduce the effects of catastrophes irrepressible ones) on society, nature and economy cannot be prevented.

Many countries, especially in Scandinavia, and in Western Europe, have been updated in the context of green financial reform, although not called as in concept of green budgeting. In this study, firstly, the relationship between green budgeting and environmental problems within

\footnotetext{
* This study was derived from the unpublished master thesis titled "Green Budgeting Approach and Evaluation" at Dokuz Eylül University, Graduate School of Social Sciences.

1 Res. Asst., Dokuz Eylül University, yapici.fatma@gmail.com
} 
global warming will be examined. Then, with the concept dimensions of green budgeting and the basic policy tools it contains, and the necessities of green budgeting will be stated. Finally, our evaluations and suggestions on green budgeting will take place.

\section{Rational of Green Budgets}

Green budgeting consists of a set of fiscal policy measures and rules to prevent environmental problems and to improve existing damage. Before explaining the conceptual aspect of green budgeting, we prefer to include environmental problems in the forefront today and to address global warming measures and the relationship between budgetary functions and environmental problems.

\subsection{Global warming}

Efforts to reduce carbon dioxide emissions in the fight against climate change as a result of global warming have begun to be demonstrated by various initiatives since the mid-20th century. $R$ \& D studies for renewable energy sources, carbon capture, and new technologies providing energy efficiency are considered as measures to reduce carbon dioxide emissions. It is another policy that the government can develop incentive mechanisms that can reduce carbon dioxide emissions by directing the market economy. Some of these incentive mechanisms are as follows (Krugman \& Wells, 2011: 250-251);

- Implementation of carbon taxes foreseen to be paid by carbon dioxide emissions,

- Determination of the upper limit of carbon dioxide emission,

- Implementation of the licensing system for the upper limit of greenhouse gas emissions in carbon dioxide and

- Development of trade system.

The carbon tax, which is one of the recommendations for reducing carbon dioxide emissions, aims to reduce the amount of carbon dioxide released into the air. Environmental tax practices in effect for this purpose are Assoc.d with the polluter pays in principle.

\subsection{Relationship between of modern functions of budgets and environment}

Since the publication of Pigou's Economics of Welfare (1928-1932), policy makers, researchers, and environmental rights advocates have discovered that economic instruments are means of internalizing environmental externalities (Milne, 2014: 5). The fact that the activities that are harmful to the environment are obliged to pay the cost to the extent that they reduce the social benefit, and they aim to influence the economic behaviors in favor of the environment. On the other hand, rewarding economic activities that have a positive impact on the environment and increase social benefit is recommended as another way to influence behaviors in the desired direction. Nowadays, while the mechanisms of rewarding actors who have a negative effect on the environment or those who have positive behaviors towards the environment in the basic framework are applied in different ways within the components of state budgets. Regulatory measures and legal limitations are also enforced for environmental purposes. Due to the developments, different functions and tasks were started to be installed in the 21st century, and the economic role of the state was reorganized and the function of regulating and controlling from interventionist function started to be weighted (Demircan, 2006: 49). 
Today, economic growth and economic stability alone do not make sense in terms of success. Sustainability of growth and stability realized due to the economic progress is crucial. For example, when Argentina was an important economic giant at the beginning of the nineteenth century, but today it is not included among the developed economies. Today, the environment we see confirms our opinion. Again, in recent years, the gained rapid economic growth and expansion of private economy in especially China, India, Mexico, South Africa have been leaded by low-wage policy, technology transfer, etc. These rapid economic progress mentioned above are often discussed in the literature whether it may be sufficient for both environmental and economic growth.

Figure 1. Sustainable development scheme

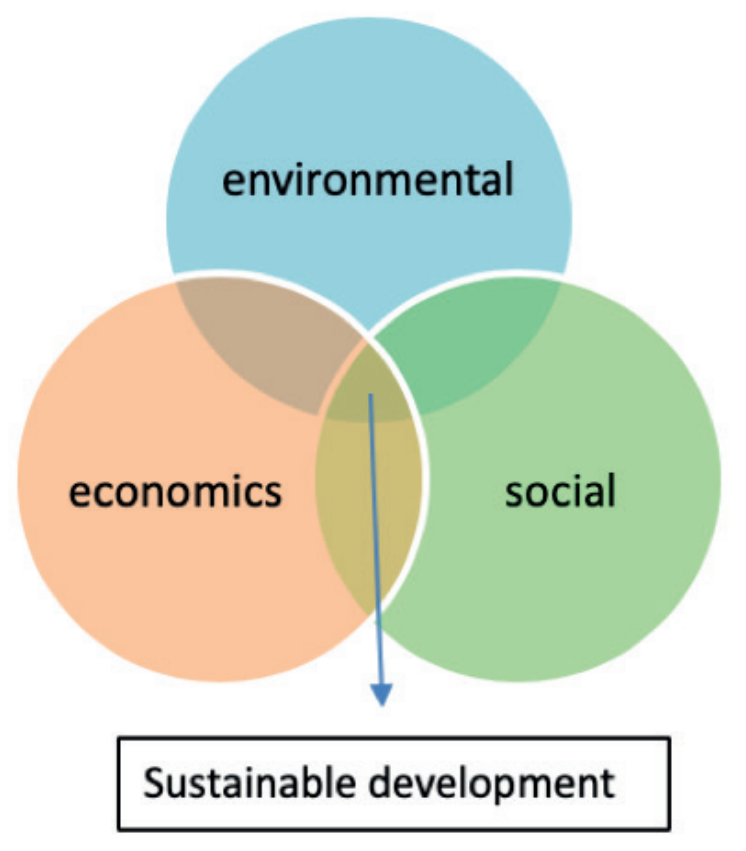

Source: Aksu, 2011: 6.

As shown in Figure 1, sustainable development is an ideal that can be achieved not only by economic progress but also by progresses in the social and environmental fields. Therefore, it is an inevitable requirement for a budget policy that includes the development objective also to carry environmental objectives and to take action for them.

Green budget instruments mostly operate to equalize social costs with the costs incurred by those who carry out activities. That is to say, thanks to an internalizing Pigouvian tax, the difference between social cost and private cost is tried to be met and the cost reflected to the society is reflected in the market price.

Due to a production or consumption activity in which they do not participate, the individuals and society affected by the benefit function in the negative sense can be damaged in a concrete way or in an abstract manner. The social costs and private costs may be equalized by introducing tax, fees and other financial obligations over environmentally damaging activities or on the product resulting from environmentally harmful production processing. This may partially resolve the disruptions in income distribution. 


\section{Green Budgeting}

Green budgeting is also referred to as ecological budgeting and environmentally sensitive budgeting. Since the 1970s it has been discussed from time to time that financial instruments need to be actively used in policies to overcome environmental problems and achieve sustainable growth.

Environmentally responsive budgeting first came to the fore in the Aalborg Convention signed in 1994. The International Council for Local Environmental Initiatives which support local activities for global sustainability and to support cities to be sustainable, flexible, resource-efficient, protecting biodiversity and low-carbon-emission had developed green budgeting approach Kılıçer, 2017: 118).

Green budgeting or environmentally sensitive budgeting is defined as a budgeting approach applying of budget policy instruments to achieve environmental goals. Green budgeting helps to achieve environmental goals, as listed below.: (OECD, http://www.oecd.org/environment/ green-budgeting/, 20.02.2019)

- Evaluating environmental impacts of budgetary and fiscal policies

- Assessing their coherence towards the delivery of national and international commitments,

- Contributing to informed, evidence-based debate and discussion on sustainable growth.

The Paris Collaborative on Green Budgeting was launched by the OECD Secretary-General Angel Gurría at the One Planet Summit in Paris on 12 December 2017. The aim of this collaboration is to align national policy frameworks and financial resources to achieve a lower level of greenhouse gas emissions and environmentally sustainable development in order to meet the Aichi Biodiversity Goals as well as United Nations Sustainable Development Goals. (OECD, http://www.oecd.org/ environment/green-budgeting/, 20.02.2019).

Collaboration is an open research platform where experts on environmental, tax, budget and financial issues work on the necessary analytical and methodological basis. To develop, test and propose tools (such as volunteering mechanisms or green budget report) to develop and support the Green Budget Strategy (such as voluntary mechanisms or green budget reports) are the for the purposes of the experts involved in the cooperation. (OECD, https://www.oecd.org /environment/cc/Flyer-Paris-Collaborative-on-Green-Budgeting.pdf, 30.12.2018) 
Table 1. The Mix of policy instruments for green budgeting

\begin{tabular}{|c|c|}
\hline Policy Tools & Contents \\
\hline \multirow[t]{4}{*}{ Voluntary mechanisms } & Promotion, persuation, exhortation, moral appeals \\
\hline & Information, education, and training \\
\hline & Empowerment of third parties (non-government organizations) \\
\hline & Voluntary standards-setting process for industry \\
\hline \multirow[t]{4}{*}{ Government regulations } & Direct regulations (legistlation, standards) \\
\hline & Planning (land use, resource management) \\
\hline & Emissions and product standards \\
\hline & Empowerment of third party regulators \\
\hline \multirow[t]{3}{*}{ Public expenditures } & Government programs and delivery \\
\hline & Public infrastructure development \\
\hline & $\begin{array}{l}\text { Financial incentives (subsidies, grants, and tax allowences) to promote, } \\
\text { for example: } \\
\text { Research and development } \\
\text { Environmental technology } \\
\text { Resource management } \\
\text { Environmental protection }\end{array}$ \\
\hline Government taxation & Taxes, levies, charges and fees \\
\hline
\end{tabular}

Sources: Gale \& Barg, 2013: 3-4.

- Voluntary mechanisms: consist of the means by which state firms and households take measures to develop behavioral measures toward to increasing environmental awareness.

- Government regulations: include the regulatory measures of the state as a legislator.

- Public expenditures: tax deductions within the scope of subsidies, preventive and corrective public expenditures, direct transfer payments, investment expenditures for developing cleaner technologies.

- Government taxation(public revenues): public revenues (taxation): Includes taxes, fees, dues, charges, and other public revenues collected for environmental purposes. To be counted as an environmental tax for a tax, it must have an environmental impact that is not less than its financial purpose. Environmental taxes are undoubtedly the most prominent tools in public revenues covered by the green budget. The distinction between environmental taxes made by Eurostat (2010) and generally accepted in the literature is as follows: energy taxes, transport taxes, pollution taxes and raw material taxes. Among the environmental taxes, the highest tax revenues gained by taxes levied on energy consumption and taxes on transportation. However, if the encouragement of these taxes in addressing greener behaviors of consumers and producers is a matter of debate. 
Various envioronmental policy tools withing fiscal policy could be applied in a country according to law. Design components of environmental taxes and eco-fees are summarized in Table 2.

Table 2. Environmental tax and eco-fee design components

\begin{tabular}{|l|l|l|}
\hline Theory & Triggering Event & Rate \\
\hline $\begin{array}{l}\text { Pigouvian tax (tax effects results; no private } \\
\text { benefit required) }\end{array}$ & $\begin{array}{l}\text { Environmentally } \\
\text { damaging activity }\end{array}$ & External costs \\
\hline $\begin{array}{l}\text { Baumol-Oates' tax (tax effects results; no private } \\
\text { benefit required) }\end{array}$ & $\begin{array}{l}\text { Environmentally } \\
\text { damaging activity }\end{array}$ & $\begin{array}{l}\text { Rate necessary to achieve } \\
\text { standard }\end{array}$ \\
\hline $\begin{array}{l}\text { Public trust eco-fee (private benefit is access to } \\
\text { public assets) }\end{array}$ & $\begin{array}{l}\text { Intrusion into public } \\
\text { asset }\end{array}$ & $\begin{array}{l}\text { Govenmentally determined } \\
\text { value of public asset made } \\
\text { available for private use }\end{array}$ \\
\hline $\begin{array}{l}\text { Licensing eco-fee (private benefit is access to } \\
\text { limited market) }\end{array}$ & $\begin{array}{l}\text { Environmentally } \\
\text { damaging activity }\end{array}$ & $\begin{array}{l}\text { Cost government decides to } \\
\text { impose to achieve desired } \\
\text { level of funding for related } \\
\text { environmental purposes }\end{array}$ \\
\hline $\begin{array}{l}\text { Regulatory eco-fee (private benefit is right to } \\
\text { pollute) }\end{array}$ & $\begin{array}{l}\text { Environmentally } \\
\text { damaging activity }\end{array}$ & $\begin{array}{l}\text { Cost government deems } \\
\text { appropriate }\end{array}$ \\
\hline $\begin{array}{l}\text { Regulatory eco-fee (private benefit is government } \\
\text { mitigation program) }\end{array}$ & $\begin{array}{l}\text { Environmentally } \\
\text { damaging activity }\end{array}$ & $\begin{array}{l}\text { Cost government decides to } \\
\text { impose to achieve desired level } \\
\text { of funding }\end{array}$ \\
\hline
\end{tabular}

Source: Milne, 2014: 13

\subsection{Requirements for green budgets}

- Political resistance: the existence of an eager political atmosphere in conducting environmental policy and in the implementation of the plan of actions- in short, medium and long termconsistently is important in achieving successful results in the long term.

- Loosened the principle of non-allocation for environmental tax revenues: to implement an allocation of environmental tax revenues to be determined only at environmental rates (such as reducing energy consumption, relocating renewable energy sources instead of fossil fuels, reducing pollution-causing activities, repairing existing environmental damage) will also be beneficial in terms of voluntary compliance with taxes.

- Establishment and revise the legal infrastructure to the extent possible to implement a green budget.

- Establishment the policy mix: environmental considerations should be taken into account and the environmentalist approach should be integrated into the set objectives when developing economic and social policies. Undoubtedly, it is only way to make possible to reach targeted improvements in the environmental area and the prevention of existing destruction through policies that support each other.

- Setting up monitoring and monitoring systems: the economic, social and environmental impacts of the green budget instruments should be assessed before and after the implementation. 


\section{Conclusion}

The existence of an environmentalist approach on the basis of public budgets is called green budgeting or ecological budgeting. The tools to be applied within the framework of green budgeting are the fees, dues, fees, charges and fines levied on the use of natural resources or pollution causing activities. Within the scope of green budgeting, expenditures on environmental protection, subsidies, incentives, as well as environmental imrovement, are designed to improve environmentally sensitive behavior. However, in line with the environmental approach adopted in budgeting, it is aimed to determine and introduce short, medium and long-term targets firstly. The success of selected policy instruments in achieving environmental goals should be assessed after implementation. At the same time, it should be subject to comprehensive assessments whether policy instruments that play a role in achieving environmental goals have a detrimental effect on other areas (fair income distribution, economic growth, global competitiveness of sectors, price stability). In addition, the addition of an environmental performance assessment report as an additional document to the state budget enacted every year will be a valuable resource for the legislators. We believe that the green budgeting itself is expected to be environmentally sustainable, and it is strongly dependent on a strong political willingness, the availability of legal infrastructure, compliance with other policies and the monitoring and follow-up of the implemented environmental financial instruments.

\section{References}

Kılıçer, E. (2017). "Çevreye Duyarlı Bütçeleme Sistemi: Bologna Örneği”, iktisat Fakültesi Mecmuası, Cilt: 67, 2017 (1) pp. 117-139.

Krugman, P. \& Wells, R. (2012). Makro iktisat, (Çev.) Oğuz, F., Akkemik, K.,A. \& Arslan, M. Ankara, Palme Yayıncılık.

Milne, J. E. (2014). “Environmental Taxes and Fees: Wrestling with Theory. Environmental Taxation and Green Fiscal Reform, Theory and Impact", Environmental Taxation and Green Fiscal Reform, (Ed.) Kreiser L., Lee, S., Kazuhiro, U., Milne, J. \& Ashiabor, H. Padstow: Edward Edgar Publishing, pp. 5-24.

Aksu, C. (2011). "Sürdürülebilir Kalkınma ve Çevre", http://geka.org.tr/yukleme/planlama/ Sektörel\%20Araşttrmalar/Sürdürülebilir\%20Kalkınma\%20ve\%20Çevre.pdf, (14.12.2018).

Eurostat. (2010). http://epp.eurostat.ec.europa.eu/cache/ITY_OFFPUB/KS-32-10-283/EN/KS32-10-283-EN.PDF, (11.12.2018).

Ener, M. \& Demircan, E. (2006). "Küreselleşme Sürecinde Yeni Devlet Anlayışı ve Türkiye”. Yönetim Bilimleri Dergisi, 4 (6), ss. 197-218.

Gale, R. \& Barg, S. (2013). "The Greening of Budgets: The Choice of Governing Instruments", $A$ Green Budget Reform, (Ed.) Gale, R., Barg, S. \& Gillies, M. A. London, Earthscan.

OECD, Paris Collaborative on Green Budgeting https://www.oecd.org/environment/cc/FlyerParis-Collaborative-on-Green-Budgeting.pdf, (30.12.2018).

OECD. Green Budgeting, http://www.oecd.org/environment/green-budgeting/, (20.02.2019). 